\section{IJ§ER}

ISSN: 2149-5939
International Journal of Social Sciences and Education Research

Online, https://dergipark.org.tr/tr/pub/ijsser

Volume: 7(2), 2021

\title{
Hotel attributes and customer's choice behavior: evidence from port Harcourt city, Nigeria
}

\author{
Yekinni Ojo Bello and Mercy Busayo Bello \\ ${ }^{a}$ PhD, University of Port Harcourt, Faculty of Management Sciences, Department of Hospitality Management and Tourism, Choba, Rivers \\ State, Nigeria.bello.yekini@gmail.com,ORCID: https://orcid.org/0000-0003-3844-0290 \\ ${ }^{b}$ Federal Polytechnic Auchi, School of Applied Sciences, Department of Hospitality Management, Auchi, Edo State, Nigeria. bel- \\ lomercy5@gmail.com,ORCID: https://orcid.org/0000-0003-3844-0290
}

\begin{tabular}{|c|c|}
\hline Article Info & Abstract \\
\hline Research Article & $\begin{array}{l}\text { This paper tested a structural model that examines the proposed relationships between hotel } \\
\text { attributes and hotel choice in respect to customers in Port Harcourt, Rivers Nigeria. The }\end{array}$ \\
\hline Received: 15 January 2021 & study used a structured questionnaire hence, a quantitative research design. Multiple re- \\
\hline Revised: 11 April 2021 & gression analysis was used for analysis of data collected using statistical package for social \\
\hline Accepted: 23 April 2021 & $\begin{array}{l}\text { science (SPSS) software version 23. The result shows that all the six hotel attributes have } \\
\text { positive and significant relationship with customer's hotel choice behavior in respect to the }\end{array}$ \\
\hline Keywords: & study area. Result further validates the proposed Hotel Choice Indicators (HCI) Model for \\
\hline Hotel attributes, & hotels in Port Harcourt City. This study contributed to the body of knowledge by proposing \\
\hline Port Harcourt City, & and validating the HCI Model for hotels in an emerging economy and Port Harcourt City in \\
\hline Location, & particular. It authenticates attribute that influence hotel choice behavior among hotel pa- \\
\hline Tariff, & trons in Port Harcourt. The study also increased the explanatory power of the push-pull \\
\hline Service Conveniences & theory in explaining hotel choice attribute or attributes in an emerging economy. \\
\hline
\end{tabular}

\section{Introduction}

The needs for people to travel outside their places of abode have increased tremendously in recent years (Igbojekwe, et al. 2013; Bello, 2015). As more people travel, the need for clean, comfortable and safe hotel services cannot be overemphasized (Bello, et al. 2016). It is pertinent to state that hotel industry is a distinctive multifaceted people-oriented industry, which significantly contributes to the service economies of nations and Nigeria in particular (Bello, 2012; UNWTO, 2013). The contributions of hotel industry to the Nigerian economy is unprecedented hence, attracted significant investment put at over US\$3 billion yearly in the past five years (Madugba, 2016; PricewaterhouseCoopers, 2017). PricewaterhouseCoopers (2015) reported that Nigerian hotel room revenue expanded at $22.6 \%$ compound annual rate of \$US1.1 billion in 2018 from \$448 million in 2014. This implies that hotel industry in Nigeria gears up to impact the national economy through corresponding revenue (Nikki, et al., 2015). However, despite the huge investment attracted to the Nigerian hotel industry, the average occupancy percentage of hotels in the country in the last six years are not encouraging. Average occupancy percentage in this context implies a statistical index used to determining the percentage of rooms available to total rooms sold (Bello $\&$ Bello, 2017). It represents the physical capacity utilization of accommodation facility hence, used to assess the degree of performance of hotels (Igbojekwe, 2008). Average occupancy percentage is therefore a practical alternative approach, in view of the reluctance of hotel managers to provide details on financial hotel performance (Sun $\& \mathrm{Lu}, 2005)$. Report has it that Nigerian hotel industry accounted for $49.8 \%, 44.7 \%, 43.6 \%, 42.4 \%$, and $42.6 \%$ occupancies in 2014, 2015, 2016, 2017, and 2018 respectively (PricewaterhouseCoopers, 2017). Also worrisome is the fact that the projected occupancy percentage for Nigerian hotels in the year 2021 is pegged at $43.6 \%$ (PricewaterhouseCoopers, 2017). Thus, a negative trend, and sharp decline in total room sold. The implication of this trends is that the physical capacity of hotel accommodation in Nigeria are underutilised, resulting in revenue loss, and low organisational productivity.

\footnotetext{
* All responsibility belongs to the researchers. All parties were involved in the research of their own free will.
}

To cite this article: Ojo Bello, Y. \& Busayo Bello, M. (2021). Hotel attributes and customer's choice behavior: evidence from port Harcourt city, Nigeria. International Journal of Social Sciences and Education Research, 7 (2), 181-193. DOI: https://doi.org/10.24289/ijsser.861886 
It had been reported that many attributes may be responsible for the low occupancy percentage of the Nigerian hotels and more so in Port Harcourt. Major among them is poor knowledge of customer's hotel choice indicators. Managers of hotels in Port Harcourt fail to understand those hotel attributes that motivates guest's choice of a hotel. Kotler, et al. (2006) opined that the first and the most critical step in service quality delivery in hotel establishments is the knowledge of the needs of customers. Given the vital role of customer's satisfaction, it is not surprising that a variety of research has been devoted to investigating hotel attributes that motivates consumer's choice of a hotel over others (Zeithaml \& Bitner, 2003). To the best of our knowledge, very limited empirical studies had reported indicators of hotel choice from the viewpoints of the customers in respect to hotels in Port Harcourt. Premise on this, the current study aims to determine the relationship between hotel choice indicators and customer's choice behaviour of hotels in Port Harcourt. Practical implications of this study include the contribution to the literature of the integrated model capable of explaining the most significant hotel choice indicators in emerging economy and more so in Port Harcourt, Nigeria. The results in this study are expected to empower hotel managers, tourists, and tourism industry practitioners on how to make decisions on high quality services for a higher rate of tourist's satisfaction based on hotel choice indicators explored in this study.

\section{Review of related literature}

\subsection{The concept of hotel attributes}

There is no stereotyped definition for the term hotel attribute. View of previous researchers on the subject matter are as follows. Wuest, et al. (1996) defined hotel attributes as various services and facilities travelers find important and satisfying in the hotel. In addition, hotel attribute is defined as those features of services offered by hotels that lead consumers to choose one hotel over others (Lewis, 1983). It is also defined as those attributes that directly arouse customer's purchase intentions and differentiates a hotel offering from competitor's offerings (Sohrabi, et al. 2011). Hotel attributes explain those characteristics that lead to higher customer's retention (Dominici \& Palumbo, 2012). It is also defined as most probable drivers of customers to select a hotel over another (Richard \& Sundaram, 1993). Hotel attribute is defined as those unique features of modern hotel industry perceived to have motivated customers to prefer a hotel to another including, keeping them satisfied (Kuo, 2009; Lam \& Zhang, 1999; Yen \& Su, 2004; Dominici \& Guzzo, 201). Hotel attributes is seen as value drivers of hotel establishment that are considered by guests to arrive at a positive overall assessment of the hotel thus, enhancing the chance of repeat patronage and positive word of mouth. (Dominici \& Palumbo, 2013). The index in the above definitions shows that hotel choice attributes are those hotel unique features which directly influences the choice process and arouse customer's purchase intentions and differentiate from competitor's offerings.

\subsection{Theoretical underpinning: The push-pull theory}

This study adopted the Push Pull theory. The Push Pull theory was developed by the E. G. Ravenstein, a Fellow of the Royal Geographic Society in the mid-eighteenth century (Baloglu \& Uysal, 1996; Bello, 2015). According to Baloglu \& Uysal (1996), Ravenstein used the Push Pull theory to explain migration patterns of people both within and between nations hence, proposed the law of migration. The theory holds that travellers embarked on a trip because they are pushed by their internal forces (intrinsic factors) and the external forces (extrinsic factors) of their origin country (Ravenstein, 1889). The theory also holds that travellers are pulled to migrate to a particular destination as a result of attractiveness of the destination as being perceived by them (Ravenstein, 1889). Push Pull theory had been variously applied in the domain of hotel choice decision among customers (Battour, et al. 2014; Kovjanic, 2014). The theory emphasised that travellers chooses a particular hotel over others as a result of the attractiveness and unique attributes of the hotel as being perceived by them (Baloglu \& Uysal, 1996; Bashar \& Ahamad, 2010) hence, the hotel pull factors. The push factors on the other hand emphasized on guest's internal forces (intrinsic factors) and the external forces (extrinsic factors) of the hotel. The push factors (i.e. guest's personal factors, and hotel external factors) are both out of scope of the current study. This is because, the current study focusses on hotel intrinsic factors (i.e. internal factors) thus, the pull factors that informed hotel choice decision among customers.

Given the vital role of customer's satisfaction, it is not surprising that a variety of research had applied the Push Pull theory to explaining hotel choice attribute or attributes that informed consumer's choice of a hotel over others (Zeithaml \& Bitner, 2003; Battour \& Ismile, 2014; Kovjanic, 2014). McCleary, et al. (1993) and Knutson (1988) found that service convenience is the top most pull factor influencing customers' choice of hotel services. Lewis (1985) opined that hotel customers seem to be more concerned with room rates in their initial hotel choice. McCleary, et al. (1993), Taninecz (1990), and Lewis \& Chambers (1989) reported that physical environment is an important hotel choice factor attracting customer's choice of hotels. Atkinson (1988), and Clow, et al. (1994) found 
that security and safety, and staff behaviour are determinants of customer's choice of hotels. Knutson (1988) revealed that prompt service is likely to influence customer's choice of a hotel. The index in the above literature shows that the results of empirical studies of customers' hotel choice indicators are inconsistent. We also argued that limited study has assessed hotel choice indicators by customers specifically in the context of Port Harcourt City. The choice of the key constructs and variables such as Hotel Tariff, Service Convenience, Security and Safety, Physical Environment, Location, and Staff Behaviour in this study reflected the boundaries this study places in limiting its scope.

\section{Empirical review}

\subsection{Hotel tariff and hotel choice}

Hotel tariff denote the price that customers pay in exchange for hotel goods and services especially accommodation, drinks and food. It is important to both the operators of hotel business and customers alike. For operators of hotel business, hotel tariff represents the returns on efforts (Igbojekwe, 2002). Aside, hotel tariff is considered as relative to the extent of satisfaction the hotel wishes to give to its customers. This implies that it denotes customer's satisfaction measurement indicator. It is pertinent to state that hotel tariff is not only important to the hotel business operators, it is also important to hotel customers as it represents the value that customers assigned to the satisfaction of needs and wants (Bello, 2018). Hotel guests expect higher level of service when they pay more (Parasuraman, et al., 1991). Hence, always perceive that the tariff charged should commensurate with the quality of services offered as well as the total satisfaction gained. This confirms hotel tariff as important determinant of customer's satisfaction and repurchase intention.

Bojanic (1996) opined that there is a significant and positive relationship between hotel tariff and hotel choice. Al-Sabbahy, et al. (2004) have also classified hotel tariff as an influencing factor of customers' future hotel choice. Mohsin \& Lockyer (2010) have identified that customer of hotels associate high importance to value for money. Kashyap \&Bojanic (2000) in their study noted that hotel tariff is significant in explaining ratings and intention to choose a hotel over others by business guests. Chu \& Choi (2000) in their research on Hong Kong hotels found that business guests stressed value for money in making their hotel choices. Ramanathan (2010) in his study of UK hotels opined that value for money is classified as a critical attribute in business guest accommodation choice. Kwenga (2012) in his study of the hotel choice criteria in church guest houses in Nairobi, Kenya, found out that fair hotel prices influence the customers in purchase of accommodation in these guest houses. Oh (1999) opined that hotel tariff exerts a significant influence on perceived service quality and subsequently their hotel choice decision. The implication of this review is the consistencies in literature regarding the influence of hotel tariff on customers' choice decision. However, the fact that the correlation between hotel tariff and customer's choice of hotel have not being tested in respect to hotels in Port Harcourt made us to assume that:

\section{$H_{1}$. Hotel tariff has a positive influence on hotel choice among hotel customers in Port Harcourt.}

\subsection{Service convenience and hotel choice}

The most important thing for a hotel to keep its customers is to establish more convenience during the service process (Reichheld \& Sasser, 1990). Berry, et al. (2002) defined service convenience as the "awareness of time and energy expenditure for customers to purchase or accept service". Chang (2007) used economic effectiveness theory to explain the multi-dimensions of service convenience to include: time convenience, location convenience, access convenience, application convenience and implementation convenience. Berry, et al. (2002) and Yüksel, et al. (2006) divided convenience into five dimensions: decision convenience, access convenience, transaction convenience, benefit convenience, and post-benefit convenience. Chang (2007) argue that service inconvenience will lead to a customers' hotel choice decision. Therefore, hotel services providers need to remain conscious of the positive implications of convenience for customers' value and loyalty (Berry, et al. 2002). If customers experience a high degree of service convenience, they will feel satisfied with the service provider and subsequently made revisit intention. Previous researchers have proposed certain important relationships linked to service convenience; for example, service convenience can directly affect customer's choice of a hotel (Fornell, et al. 1996; Seiders, et al. 2000; Berry, et al. 2002; Chow, et al. 2007). Keaveney (1995) argues that service inconvenience lead to a customer switching behaviour. The implication of this review is the consistencies in literature regarding the influence of service convenience on customer's choice of hotel. However, the fact that these studies were not examined in respect to hotels in Port Harcourt made us to assume that:

$\mathrm{H}_{2}$. Service convenience has a positive influence on hotel choice among customers in Port Harcourt. 


\subsection{Security and safety and hotel choice}

It is well established that safety and security are attribute of concern for travelers and hotel guests. Customers want to see visible indicators of security in hotels hence, security and safety attribute are critical to customers' choice of a hotel (Enz \& Taylor, 2002; Himmelberg, 2004). Previous studies have explored the importance of hotel safety and security to travelers generally (Mariner, 1995; Himmelberg, 2004). Hinkin \& Tracey (2003a, 2003b) in their studies found that security and safety ranked as the number-one factor contributing to hotel choice decision by customers. Ananth, et al. (1992) in their survey of 510 travellers, asking them to rate the importance of 57 hotels attributes that influences their hotel choice decision. The results showed that attributes related to security is one of the most-rated attributes across all age categories. Chu \& Choi (2000) in their study of 343 Hong Kong tourists about the hotel attributes that influences their hotel choice. They reported that security is one of the main attribute for hotel choice. Safety and security are important attribute to customers when choosing a destination and when selecting a hotel to stay (Ghazi, 2015). Clow, et al. (1994) indicated that security and safety is one of the most important attributes influencing leisure travellers' choice of hotel. Atkinson (1988) found that safety and security is identified as one of the most attributes for travellers' choice of hotel. However, the fact that these studies were not examined in respect to hotels in Port Harcourt made us to assume the following hypotheses:

\section{$H_{3}$. Security and safety have a positive influence on hotel choice behaviour among customers in Port Harcourt.}

\subsection{Physical environment and hotel choice}

The pleasing environment has a potential to stimulate customer's hotel choice behaviour, buying habit and produce more profit. This implies that the physical environment of an organization consists of elements, such as overall layout, design, and decoration. Wakefeild \& Blodgett (1994), stated that the physical environment includes elements such as layout, interior architecture and decoration, lighting, music, aromas and cleanliness. Physical environment in this sense emphasised on ambient cues, design cues, and social cues that attracts customers to choose a hotel over others (Reimer \& Kuehn, 2005). Wakefeild \& Blodgett (1994) reports that physical environment of a hotel influences not only consumers cognitive, emotional, and physiological states but their hotel choice behaviour. Kokko (2005) suggests that hotel physical environment is often perceived by customers as the single most positive characteristic of the establishment. This is because the physical surrounding creates an expectation of hospitality experience even before customers are served (Young, et al. 2007). Liu \& Jang (2009) study shows that increasing ambience by scent can improve evaluations of a hotel and create higher tendency of choosing a hotel over others.

Many empirical studies have shown how environment influences customer's satisfaction and predicts repurchase behaviour (Knutson \& Patton, 1995; Hui et al. 1997; Chang, 2000; Mattila, 2001; Chebat \& Michon, 2003; Barber \& Scarcelli, 2009; Liu \& Jang, 2009; Lim, 2010). Kwenga (2012) in his study of the hotel choice criteria of customers in church guest houses in Nairobi, Kenya, found out that good physical environment influences the customers in purchase of accommodation in these guest houses. Wakefield \& Blodgett (1996) study shows that hotel facility aesthetics, seating comfort and cleanliness significantly affect customer's satisfaction and subsequently, their choice decision. In addition, Chang (2000) also mentioned physical environment of a hotel as having direct relationship with customer's satisfaction and subsequently future revisit intention. Chen \& Hsieh (2011) study shows that pleasure and arousal environment will stimulate customers spend approximately 12 percent more in average. Soriano (2002) mentioned that comfortable atmosphere will make customers to stay longer in the hotel. Additionally, Brady \& Cronin (2001) stated that environment can have a significant impact on perception of overall quality, which turn to affect customer's choice behaviour. The implication of these review is the consistencies in literature regarding the influence of hotel physical environment on customer's choice decision. However, the fact that the correlation between physical environment and customer's choice has not being tested in respect to hotels in Port Harcourt made us to assume that:

H. Physical environment has a positive influence on hotel choice behaviour among customers in Port Harcourt.

\subsection{Location and hotel choice}

Rivers, et al. (1991) examined hotel choice decisions of members and non-members of frequent guest programs. The outcome of their study showed that a hotel's location is an essential factor which strongly influences tourist's hotel choice. Knutson (1998) opined that both business and leisure travelers considered location convenience as one of the major hotel attributes that determines their hotel choice. Ananth, et al. (1992) in their survey of 510 travellers showed that convenient of location has positive correlation to hotel choice. Barsky \& Labagh 
(1992) reported that hotel location is one of the major attributes that influences both business and leisure traveler's choice of hotel. Chu \& Choi (2000) and Xue, et al. (2008) reported that business travelers are more concerned about hotel location hence, informed their choice decision. Kim (2014) examined the relationship between hotel attributes and leisure traveller's satisfaction. He opined that hotel location mostly informed the satisfaction of leisure travelers. Tsai, et al. (2011) in their study of differences in the important ratings of hotel choice criteria between Mainland Chinese and foreign individual travelers to Hong Kong found that location is the most important hotel choice factor for business travelers. Yusoff \& Abdullah (2010) identified convenient location as the highest ranked hotel choice factor by Middle East tourists. The fact that the correlation between hotel location and customer's choice have not being tested in respect to hotels in Port Harcourt made us to assume the hypotheses that:

\section{H5. Location has a positive influence on hotel choice behaviour among customers in Port Harcourt.}

\subsection{Staff behavior and hotel choice}

Numerous studies show that the degree to which hotel employees' attitudes impact on customer's satisfaction and subsequently, hotel choice cannot be overemphasized (Bach \& Milman, 1996; McColl-Kennedy \& White, 1997; Mayo \& Collegian, 1997; Kriegl, 2000; Kuo, 2009). Clow, et al. (1994) indicated that one of the most important attributes influencing leisure travellers' choice of hotel is staff-customer personal interactions. Atkinson (1988) found that courtesy and helpfulness of staff is identified as one of the top-most attributes for traveller's choice of hotel. Hsieh, et al. (2008) opined that "the quick problem-solving abilities by the service personal", is an important hotel choice attribute in Taiwan hot-spring tourism industry. Cladotte \& Turgeon (1988) in their analysis of data provided by the American Hotel and Motel Association observed that staff attitude is the critical considerations for guests' hotel choice. Barsky \& Labagh (1992) stated that staff attitude is one of the major determinants of hotel choice. The fact that the correlation between hotel staff behaviour and customer's choice decision have not been tested in respect to hotels in Port Harcourt made us to assume that:

\section{H6. Staff behaviour has a positive influence on hotel choice behaviour among customers in Port Harcourt.}

\subsection{Conceptual framework of the study}

The hotel choice indicators (HCI) model for hotels in Port Harcourt City is proposed in this study as shown in Figure 1. The HCI model shows six hotel attributes or indicators as independent variables and customers' choice as the dependent variable. The independent variables include; Hotel Tariff, Service Convenience, Security and Safety, Physical Environment, Location, and Staff Behaviour. The model is expected to explain the relationship between these six hotel attributes and the dependent variable (i.e. Customers Choice Behaviour) in the context of hotels in Port Harcourt, Rivers State.

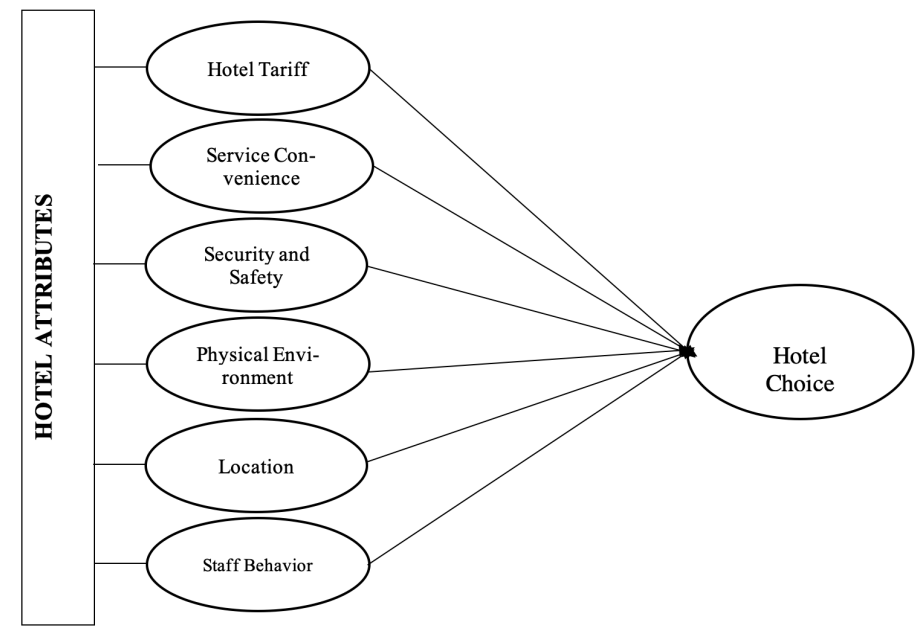

Figure 1. The Hotel Choice Indicators (HCI) model for hotels in Port Harcourt City.

\section{Research methodology}

This research adopts a survey research design to establish the relationship between hotel attributes and hotel choice by customers in Port Harcourt City. The 33-items Hotel Choice Attribute Instrument developed by Sohrabi et al. (2011) to explore hotel choice attribute in Tehran were adopted and modified into 19 items (Location -2 items; Service Convenience- 8 items; safety and security -4 items; physical environment -2 items; Staff behavior 
- 3 items). Also the 61 items hotel choice attributes instrument developed by Choosrichom (2011) to determine attribute influencing the choice of hotels/Resorts in Lanta Yai Island, Krabi, Thailand by international travelers were adopted and modified into 11 attributes (Location -1 item; Hotel tariff- 2 items; Safety and security- 4 items; Physical environment 5 item; staff behavior - 3 items). Furthermore, 16 items were adopted and modified from hotel choice instrument developed by Kowisuth (2015) to investigate attribute influencing hotel choice of tourists travelling with children in Phuket (Location -4 items; Hotel tariff -3 items; and Staff behavior -4 items). In addition, a 5-items hotel choice scale developed by Bello (2018) were adapted and used for this study. The questionnaire design has three sections; Section A contains the respondent's bio data such as age marital status, gender, academic qualification, etc. Section B contains the hotel attributes structured on a five (5) point likert scale with weights assigned as follows: 5 -strongly agree, 4 - agree, 3 - neutral, 2 - disagree, and 1 - strongly disagree. The research population for this study comprised of customers that patronise the 10 selected hotels as shown in Table 1. These hotels were selected for the study due to its popularity among hotel patrons in Port Harcourt City and its environs. To determine the exact sample size for the present study, the suggestion in Freneund \& William (2009) for determining infinite population were upheld. The authors proposed the formula to determining the sample size ( $n)$ as follows:

$$
n=\frac{\left(Z_{\alpha / 2}\right)^{2} P Q}{e^{2}}
$$

Where

$P=$ Probability for positive response.

$Q=$ Probability for negative response.

$e=$ Tolerable error $(0.05)$.

$Z_{\alpha / 2}=1.96$ from the critical table $Z$ of 0.05 under infinity $\infty$.

$\alpha=0.05$, the significant level

$n=$ Sample size

Applying this formula to the present study, the sample size (n) is put at 323. Since 10 selected hotels in Port Harcourt City are being examined in this study including, the fact that the populations of patrons in each of these hotels are unknown, the researchers therefore divided 323 by 10 of the sampled hotels hence, 33 customers in each of the 10 selected hotels were sampled hence, the sample size of 330 . Since is practically impossible to access the nominal register of all the customers that patronises the 10 selected hotels in Port Harcourt City been examined in this study, the researchers therefore opted for non-probability sampling with convenience sampling technique. The researchers personally visited each of the 10 targeted hotels in Port Harcourt City and, thus, administered the structured questionnaires until the sample size of 330 is met. Multiple regressions analysis that allow the exploration of the interrelationship among a set of variables (Pallant, 2010) were adopted for the analysis of data collected. According to Hair, et al. (2006), it is a general statistic technique used to examine one dependent variable and several independent variables. Before proceeding with the analysis of objectives in the present study, the researchers carefully screen the data in terms of missing values, influential outliers, normality, and multicollinearity using statistical package for social science (SPSS) software version 23.

\section{Results}

\subsection{Demographic distribution of respondents}

The gender distribution of the respondents indicates that $63.3 \%$ of the respondents are males and $36.7 \%$ are females. This implied that majority of the participants in this study are males. In terms of marital status, $66.4 \%$ of the respondents are single, $32.7 \%$ are married, and $.9 \%$ are divorced. This implied that majority of the participants in this study are single, followed by the married. The religion distribution of respondents used in the present study includes: Christianity (13.9\%), Islam (71.8\%) and others (14.2\%). This shows that majority of participants in this study are Muslims followed by Christians with only very few Other's participants (i.e. traditional believers). Analysis of participants' distribution by education qualification shows that $35.5 \%, 31.2 \%$, and $33.3 \%$ of the respondents had HND/ Bachelors, PGD/Masters Degrees, and Ph.D respectively. This implies that majority of participants used in the study are holders of HND/ Bachelors qualifications, followed by those that has Ph.D qualification. The 
analysis of respondents' length of stay distribution shows that $53.3 \%$ of the respondents spends $5-6$ nights in the hotel before checking-out, $29.1 \%$ of the respondents spends $3-4$ nights, while $17.6 \%$ spends $1-2$ nights. This implies that majority of the respondents spend 5-6 nights before checking-out.

\subsection{Reliability analysis}

The outcome of the reliability analysis shows that each of the six hotel attributes has a Cronbach's alpha readings as follows; Location, $(\alpha=.784$, Tariff Structure, $(\alpha=.846)$, Service Convenience, $(\alpha=.784)$, Safety and Security, $(\alpha=.720)$, Physical Environment, $(\alpha=.832)$, and Staff Behaviour, $(\alpha=.783)$. The Cronbach's alpha readings of the dependent variable- Hotel Choice show, $(\alpha=.783)$. These results justify that all the items of the six hotel attributes, and Hotels' Choice construct in respect to Port Harcourt City, Nigeria has Cronbach's alpha value $>.70$. This shows the internally consistency of the items in the instrument (Hair et al. 2006).

\subsection{Correlations of hotel attributes and hotel choice}

Data collected were analysed using Pearson moment correlation to determine the relationship between hotel attributes and customer's choice of hotels in Port Harcourt City, Nigeria. The result is shown in Table 1.

Table 1. Correlations of hotel attributes and hotel choice

\begin{tabular}{lccc}
\hline Variables & R & P & Level \\
\hline Hotel Choice (HOTC) & -- & - & Low \\
Location (LOC) & 0.241 & 0.000 & Medium \\
Tariff Structure (TAR) & 0.357 & 0.000 & Medium \\
Service Conveniences (SERC) & 0.373 & 0.000 & Medium \\
Safety and Security (SAFS) & 0.373 & 0.000 & Large \\
Physical Environment (PHYE) & 0.536 & 0.000 & Large \\
Staff Behaviour (STAB) & 0.971 & 0.000 & \\
\hline
\end{tabular}

*. Correlation is significant at the 0.05 level (2-tailed).

**. Correlation is significant at the 0.01 level (2-tailed).

Source: (Authors Computation, 2019).

The results as shown in Table 1 depicted that there is positive and significant correlation between the six dimensions of hotel attributes: Hotel Location (LOC) $(r=0.241 ; p=0.000)$, Tariff Structure (TAR) $(r=0.357 ; p$ $=0.000)$, Service Conveniences (SERC) $(r=0.373 ; p=0.000)$, Safety and Security (SAFS) $(r=0.373 ; p=0.000)$, Physical Environment (PHYE) $(r=0.536 ; p=0.000)$, and Staff Behaviour (STAB) $(r=0.971 ; p=0.000)$. This suggests that all the tested variables have a positive and significant relationship with customer's choice of hotels (HOTC) in respect to Port Harcourt City. In terms of the strength of the relationship, the results shown that hotel location has a low and positive relationship $(r=0.241)$, Tariff Structure, Service Conveniences, and Safety and Security has a medium and positive relationship $(r=0.357),(r=0.373)$, and $(r=0.373)$ respectively. The study further shows that Physical Environment, and Staff Behaviour has a large and positive relationship $(r=0.536)$, and $(r=0.971)$ respectively. Therefore, the alternative hypothesis was accepted which states that there is a significant and positive relationship between the dimensions of hotel attributes (Hotel Tariff, Service Convenience, Security and Safety, Physical Environment, Hotel Location, and Staff Behaviour), and Hotel Choice by customers in Port Harcourt City, Rivers State Nigeria.

Table 2. Model summary

\begin{tabular}{|c|c|c|c|c|c|c|c|c|c|}
\hline \multirow[t]{2}{*}{ Model } & \multirow[t]{2}{*}{$\mathrm{R}$} & \multirow[t]{2}{*}{ R Square } & \multirow{2}{*}{$\begin{array}{l}\text { Adjusted R } \\
\text { Square }\end{array}$} & \multirow{2}{*}{$\begin{array}{l}\text { Std. Error of } \\
\text { the Estimate }\end{array}$} & \multicolumn{5}{|c|}{ Change Statistics } \\
\hline & & & & & $\begin{array}{l}\text { R Square } \\
\text { Change }\end{array}$ & F Change & $\mathrm{df1}$ & $\mathrm{df} 2$ & Sig. F Change \\
\hline 1 & $.971^{\mathrm{a}}$ & .944 & .943 & .784 & .944 & 1084.916 & 5 & 324 & .000 \\
\hline
\end{tabular}

a. Predictors: (Constant), STAB, LOC, SAFS, TAR, PHYE

b. Dependent Variable: HOTC

Source: (Authors Computation, 2019).

From Table 2, it was depicted that the value of R-square is .944. This indicates that the goodness of fit of the Hotel Choice Indicators (HCI) Model for Hotels in Port Harcourt City is statistically significant. The adjusted Rsquare value of .943 is also statistically significant which indicate that after taking into accounts; the number of regressors, the HCI Model explains about $94 \%$ of the variation in customer's choice of hotels in Port Harcourt City, Rivers State. Thus, the remaining 6\% is due to other attribute and residuals. Also, the multiple $\mathrm{R}(\mathrm{R}=.971)$ revealed a significant large relationship between independent variables (i.e. Hotel Attributes) and the dependent variable (i.e. Hotel Choice) in respect to customers in Port Harcourt City. 
Table 3. ANOVA

\begin{tabular}{|ll|c|c|c|c|c|}
\hline Model & & Sum of Squares & df & Mean Square & F & Sig. \\
\hline 1 & Regression & 3338.332 & 5 & 667.666 & 1084.916 & $.000^{\mathrm{b}}$ \\
& Residual & 199.392 & 324 & .615 & & \\
& Total & 3537.724 & 329 & & & \\
\end{tabular}

a. Dependent Variable: HOTC

b. Predictors: (Constant), STAB, LOC, SAFS, TAR, PHYE

Source: (Authors Computation, 2019).

From Table 3, the result of the analysis shows that $F$ value was significant $(p=.000)$. This shows that the model was valid. Thus, based on the findings it can be concluded that there was a linear relationship between the six predictors of hotel (Hotel Tariff, Service Convenience, Security and Safety, Physical Environment, Hotel Location, and Staff Behaviour), and Hotel Choice by customers in Port Harcourt City, Rivers State Nigeria.

Table 4. Coefficients

\begin{tabular}{|c|c|c|c|c|c|}
\hline \multirow[t]{2}{*}{ Model } & \multicolumn{2}{|c|}{ Unstandardized Coefficients } & \multirow{2}{*}{$\begin{array}{c}\begin{array}{c}\text { Standardized Co- } \\
\text { efficients }\end{array} \\
\text { Beta }\end{array}$} & \multirow[t]{2}{*}{$\mathrm{t}$} & \multirow[t]{2}{*}{ Sig. } \\
\hline & B & Std. Error & & & \\
\hline 1 (Constant) & .705 & .323 & & 2.181 & .030 \\
\hline LOC & -.011 & .009 & -.019 & -1.227 & .221 \\
\hline TAR & -.014 & .015 & -.016 & -.977 & .329 \\
\hline SAFS & -.010 & .010 & -.015 & -.977 & .329 \\
\hline PHYE & -.011 & .013 & -.014 & -.834 & .405 \\
\hline STAB & .858 & .014 & .997 & 59.768 & .000 \\
\hline
\end{tabular}

a. Dependent Variable: HOTC

Source: (Authors Computation, 2019).

From Table 4, in comparing the contribution of each independent variable, Beta values are used. As illustrated in the standardized coefficient column, staff behaviour (STAB) makes the strongest unique contribution to customer's choice of hotels in Port Harcourt City, Rivers State, Nigeria with $(\beta=.977)$, followed by hotel location (LOC) with $(\beta=.019)$, tariff structure (TAR) with $(\beta=.016)$, safety and security (SAFS) made the fourth relative contribution, $(\beta=-.015)$.

\section{Discussion}

The study sought to establish the relationship between hotel attributes and customers' choice of hotels in Port Harcourt City, Rivers State, Nigeria. The major findings for each objective are as follows.

Regarding the first objective that examine the relationship between hotel tariff and customer's choice of hotels in Port Harcourt City, the study found that hotel tariff has a positive and significant relationship with the customer's choice of hotels in Port Harcourt City. This finding corresponds with existing literatures. Bojanic (1996) opined that there is a significant and positive relationship between hotel tariff and hotel choice decision. Al-Sabbahy, et al. (2004) have also classified hotel tariff as an influencing factor of customers' future hotel choice behaviour. Kashyap \& Bojanic (2000) in their study noted that hotel tariff is significant in explaining ratings and intention to choose a hotel over others by business guests. Chu \& Choi (2000) in their research on Hong Kong hotels found that business guests stressed value for money in making their hotel choices. Ramanathan (2010) in his study of UK hotels opined that value for money is classified as a critical attribute in business guest accommodation choice. Kwenga (2012) in his study of the hotel choice criteria in church guest houses in Nairobi, Kenya, found out that fair hotel prices influence the customers in purchase of accommodation in these guest houses. In respect to the relationship between Service Convenience and Hotel Choice among hotel patrons in Port Harcourt City, Nigeria, the finding shows that Service Convenience positively influences Hotel Choice among hotel patrons in Port Harcourt City, Nigeria. This finding is in agreement with Keaveney (1995) who argues that service inconvenience lead to customers' switching his choice behavior of hotels. Previous researchers have also established the relationships between service convenience customers' choice of a hotel (Berry, et al. 2002; Chow, et al. 2007; Fornell, et al. 1996; Seiders, et al. 2000).

Furthermore, on the objective that determines the relationship existing between security and safety and hotel choice in respect to hotel patrons in Port Harcourt City, Rivers State, Nigeria, the study found a positive and 
significant relationship. This finding agrees with Hinkin \& Tracey (2003a, 2003b). The authors opined that security and safety ranked as the number-one factor contributing to hotel choice by customers. Ananth, et al. (1992) in their survey of 510 travellers, asking them to rate the importance of 57 hotel attributes that influences their hotel choice decision. The results showed that security is one of the top-most-rated attributes across all age categories. Chu \& Choi (2000) in their study of 343 Hong Kong tourists about the hotel attributes that influences their hotel choice. They reported that security is one of the main attribute for hotel choice. Atkinson (1988) found that safety and security is identified as one of the top-most attributes for travellers choice of hotel. In respect of objective four, the relationship between physical environment and hotel choice was determined. The study found a positive and significant relationship between physical environment and hotel choice. This finding agrees with Kwenga (2012) in his study of the hotel choice criteria of customers in church guest houses in Nairobi, Kenya, found out that good physical environment influences the customers in purchase of accommodation in these guest houses. Wakefield \& Blodgett (1996) study shows that hotel facility aesthetics, seating comfort and cleanliness significantly affect customers' satisfaction and their choice decision.

In addition, the objective that examined the relationship existing between location and hotel choice behavior in respect to hotel patrons in Port Harcourt City, found a positive and significant relationship. This finding agrees with Ananth, et al. (1992) in their survey of 510 travellers. Hence, showed that convenient of location has positive correlation to hotel choice. Barsky \& Labagh (1992) reported that hotel location is one of the major attributes that influences both business and leisure travelers' choice of hotel. Chu \& Choi (2000) and Xue, et al. (2008) reported that business travelers are more concerned about hotel location hence, informed their choice decision. Kim (2014) opined that hotel location mostly informed the satisfaction of leisure travelers. On the objective which determined the relationship between staff behaviour and hotel choice in respect to hotel patrons in Port Harcourt City, Nigeria, the finding shows a positive and significant relationship between the two variables. This finding conforms to Cladotte \& Turgeon (1988) hence, in their analysis of data provided by the American Hotel and Motel Association observed that staff attitude is the critical considerations for guests' choice of hotel. Barsky \& Labagh (1992) stated that staff attitude is one of the major determinants of hotel choice decision. Atkinson (1988) found that courtesy and helpfulness of staff is identified as one of the top-most attributes for traveller's choice of hotel. Finally, on the objective which determined the hotel attribute that mostly predicts customers' choice of hotels in Port Harcourt City, the finding shows that staff behaviour (STAB) makes the strongest unique contribution to customer's choice of hotels in Port Harcourt City followed by hotel location, tariff structure, and subsequently, safety and security. This finding conforms to Atkinson (1988) who reported that courtesy and helpfulness of hotel staff is identified as one of the top-most attributes for traveller's choice of hotel. Barsky \& Labagh (1992) stated that staff attitude is one of the major determinants of hotel choice decision.

\section{Conclusions}

One of the conclusions that could be drawn from this study is that hotel patrons in Port Harcourt City choose hotels due to the location of the hotel in clean climate district, access to shopping centers, serene and quite area, and access to major tourist attractions. In addition, hotels that offers value for money for food and beverages served, friendly tariff for rooms, and other services offered are likely to be highly patronized by Port Harcourt customers. Furthermore, hotel that promote service conveniences in terms of e-banking services, ease of making airline reservations, and advance reservations among others are likely to be patronized by customers in Port Harcourt. Hotels that parades visible security staff presence, have emergency services, electronic key cards, and fire escape and alarm facilities shall enjoy the patronage of Port Harcourt customers. Hotels in Port Harcourt that maintains general hygiene, whose design/layout conform to modern architecture, has adequate parking space, provides comfortable ambience, and green space may enjoy the patronage of customers. Finally, the extent at which hotel staff provides efficient services, display attribute of being polite and friendly, neat, and understanding including, have multi-lingual skills are plus to attracting the patronages by Port Harcourt customers.

\subsection{Theoretical implications}

Theoretically, the push pull theory was successfully applied in the present study to explaining hotel attributes that informed guest's choice of hotel establishment in Port Harcourt, Rivers State Nigeria. The hotel choice indicators (HCI) model for hotels in Port Harcourt City were proposed and validated in this study. The result shows a linear relationship between the six hotel pull factors (i.e. Hotel Tariff, Service Convenience, Security and Safety, Physical Environment, Hotel Location, and Staff Behaviour), and Hotel Choice by customers in Port Harcourt City, Rivers State Nigeria. The implication of this is that the new model offers an understanding of hotel attributes (i.e. Pull factors) that informed the choice of hotels in Port Harcourt. 


\subsection{Practical implications}

Findings in the current study provides significant benefits not only to the managers of hotel business, but also to the government of Rivers State, Nigeria. Managers and operators of hotel businesses in Port Harcourt should give more attention to sustenance of the physical environment and aesthetic values of their hotels. Also, the government of Rivers State and the private sector should aggressively invest more on security infrastructure to guarantee safety of hotel patrons in Port Harcourt and its environs. In addition, the government of Nigeria and more so Rivers State should invest in public infrastructure to help reduce cost of running hotel business. This will promote price competitiveness and reduces hotel tariff structure hence, enhances customer's patronage. Furthermore, hotel business operators in Rivers State should endeavor to train their staff on the modern hotel service staff and customers relationship psychologies. This will help shape their staff behavior and in turn enhances customer satisfaction. Partnership of the management of hotel businesses with major service providers such as MTN, Globacom among others to ensure stable and discounted Wi-Fi connections will be an added advantage to hotel choice in Port Harcourt. Finally, banking services and ease of e-transaction at the hotel by the customers will add more flavor to the image of hotels in Port Harcourt.

\subsection{Limitations of the study}

Despite the incisive results, one of the major limitations of this study is that only hotel patrons in Port Harcourt City was focused, thus, did not consider hotel patrons in other local government areas of Rivers State and more so other States across Nigeria. If this is done it may provide a more in-depth insight and more meaningful results.

\section{Author contribution statements}

Y. Ojo Bello and M.Busayo Bello contributed equally to the design and implementation of the research, to the analysis of the results and to the writing of the manuscript.

\section{Disclosure statement}

No potential conflict of interest was reported by the authors.

\section{Ethics committee approval}

All responsibility belongs to the researchers. All parties were involved in the research of their own free will.

\section{References}

Al-Sabbahy, H., Ekinci, Y. and Riley, M. (2004). An investigation of perceived value dimensions: implications for hospitality research. Journal of Travel Research, 42, (3), 226-234.

Ananth, M., DeMicco, F.J., Moreo, P.J., and Howey, R. M . (1992 ). Marketplace lodging needs of mature travellers. The Cornell Hotel and Restaurant Administration Quarterly, 33, (4), 12-24.

Atkinson, A. (1988). Answering the Eternal Question: What Does the Customer Want? . The Cornell Hotel and Restaurant Administration Quarterly, 29, (2), 12-14.

Bach, S. A., and Milman, A. (1996). A novel technique for reviewing a hospitality management curriculum. Hospitality and Tourism Educator, 8, (1), 37-40.

Baloglu, S.and Uysal, M. (1996). Market Segments of Push and Pull Motivation: A Canonical Correlation Approach. International Journal of Hospitality Management, 8, 32-38.

Barber, N., and Scarcelli, J. M. (2009 ). Clean restrooms: How important are they to restaurant consumers? Journal of Foodservice, 20, (6), 309-320.

Barsky, J., and Labagh, R. (1992). A strategy for customer satisfaction. The Cornell Hotel and Restaurant Administration Quarterly, 35, (5), 32-40.

Bashar, A. A. and Ahmad, P.M.S. . (2010). An Analysis of Push and Pull Travel Motivations of Foreign Tourists to Jordan. International Journal of Business and Management, 5, (12), 41-50.

Battour, M., and Ismail, M.N;. (2014). The Role of Destination Attributes in Islamic Tourism. Retrieved from SHS Web of Conferences 12, p.1-8: http://www.shs-conferences.org/articles/shsconf/pdf/2014/09/shsconf_4ictr2014_01077.pdf

Bello, Y. O. (2012). Hospitality Economics (A Simplified Approach) in the Nigerian Hospitality Industry (2nd Ed.). Ondo: Grace Excellent Publishers.

Bello, Y. O. (2015). Destination Choice process among Higher Education Students in Malaysia . University Putra Malaysia: Doctorate Degree Thesis Submitted to School of Graduate Studies.

Bello, Y. O. (2018). Hospitlaity and Tourism Economics. Ondo: Grace Excellent Publishers. 
Bello, Y. O., Udi, I. O., Bello, M. B., and Raja, N. R. Y. (2016). Introduction to Hospitality management. Ondo: Grace Excellent Publishers.

Bello, Y.O., \& Bello, M. B. (2017). Hotel Front Office Management; The Contemporary Approach. Ondo: Grace Excellent Publishers.

Berry,T., Shostack, G, and Upah, G. (2002). Emerging Perspectives on Services Marketing . Chicago: American Marketing.

Bojanic, D. C. (1996). Consumer perceptions of price, value and satisfaction in the hotel industry: An exploratory study. Journal of Hospitality and Leisure Marketing, 4,(1), 5-22.

Brady, M. K., and Cronin, J. J. (2001). Some new thoughts on conceptualizing perceived service quality: A hierarchical approach . Journal of Marketing, 65, (3), 34-49.

Cadotte, E.R., and Turgeon, N. (1988). Key attribute in guest satisfaction. The Cornell Hotel and Restaurant Administration Quarterly, 28, (4), 45-51.

Chang, K. (2007). The impact of perceived physical environments on customers' satisfaction and return intention. Journal of Professional Services Marketing, 21, (2), 75-85.

Chebat, J., and Michon, R. (2003). Impact of ambient odors on mall shoppers' emotions, cognition, and spending. Journal of Business Research, 56, 529-539.

Chow, I. H.-s., Lau, V. P., Lo, T. W.-c., Sha, Z., and Yun, H. (2007). Service quality in restaurant operations in China: Decisionand experientialoriented perspectives . Hospitality Management, 26, 689-710.

Chu, R.K.S., and Choi, T. (2000). An importance-performance analysis of hotel choice attribute in the Hong Kong hotel industry: a comparison of business and leisure travelers. Tourism Management, 21, 363-377.

Clow, K. E., Garretson, J. A., and Kurtz, D. L. (1994). An Exploratory Study into the Purchase Decision Process used by Leisure Travellers in Hotel Choice. Journal of Hospitality and Leisure Marketing, 2, (4), 53-72.

Dominici, G. and Guzzo, R. (2010). Customer Satisfaction in the Hotel Industry: A Case Study from Sicily. International journal of Marketing Studies, 2, (2), 3-12.

Dominici, G. and Palumbo, F. (2012). How to Build an E-learning Product: Attribute for Student / Customers' Satisaction. Business Horizons, 56, (1), 87-96.

Dominici, G., and Palumbo, F. (2013). The Drivers of Customer Satisfaction in the Hospitality Industry: Applying the Kano Model to Sicilian Hotels. International Journal of Leisure and Tourism Marketing, 3, (3), 215-236.

Enz, C.A., \&Taylor, M.S. (2002). The safety and security of U.S. hotels: Apost-September11 report. Cornell Hotel and Restaurant Administration Quarterly, 43, (5), 119-136.

Fornell, C., Johnson, M. D., Anderson, E. W., Cha, J., and Bryant, B. E. (1996). The American customer satisfaction index: Nature, purpose, and findings. The Journal of Marketing, 60, (4), 7-18.

Freneund, J. E., and William, F.J. (2009). Quick Statistics. London: Penguin.

Ghazi, K. M. (2015). Safety and Security Measures in Egyptian Hotels . Journal of Hotel and Business Management, 4, (1),111.

Hair, J. F., Black, W. C., Babin, B. J., Anderson, R. E., and Tatham, R. L. (2006). Multivariate Data Analysis (6th Ed.) . Upper Saddle River, NJ : Pearson Prentice Hall.

Himmelberg, M. (2004). Safety is a top concern for travelers, who like to see visible security. Knight Ridder Tribune Business News.

Hinkin, T.R., and Tracey, J.B. (2003a). The service imperative: Attribute driving meeting effectiveness . Cornell Hotel and Restaurant Administration Quarterly, 44(5/6), 17-26.

Hinkin, T.R., and Tracey, J.B. (2003b). Continued relevance of "Attribute driving meeting effectiveness. Cornell Hotel and Restaurant Administration Quarterly, 44, (5/6), 27-30.

Hsieh, L.F., Lin, L.H., and Lin, Y.Y. (2008). A service quality management architecture for hot spring hotels in Taiwan. Tourism Management, 29, 429-438.

Hui, M. K., Dube, L., and Chebat, J. (1997). The impact of music on consumer's reaction to waiting for services . Journal of Retailing, 73, 87-104.

Igbojekwe, P. A. (2002). Management Control System, Theory and Practice in the Hospitality Industry. Owerri: Heins Nigeria Publisher Ltd.

Igbojekwe, P. A. (2008). Managing Housekeeping Operations. Owerri: J. Emeka - Njoku and Sons Enterprise.

Igbojekwe, P. A., Okoli, C. I., and Ugo-Okoro, C. (2013). Attitude to Recreation: A Hindrance to Development of Tourism Industry in Nigeria. International Journal of Art and Commerce, 2, (2), 12-23.

Kashyap, R. and Bojanic, D.C. (2000). A structural analysis of value, quality, and price perceptions of business and leisure travelers. Journal of Travel Research, 39, 45-51. 
Keaveney, S. (1995). Customer switching behavior in service industries: An exploratory study. Journal of Marketing, 59, (2): 71-82.

Kim, J.H. (2014). The Antecedents of Memorable Tourism Experiences: The Development of a Scale to Measure the Destination Attributes Associated with Memorable Experiences. Tourism Management, 44: 34-45.

Knutson, B. (1988). Frequent Travelers: Making them Happy and Bringing them Back. The Cornell Hotel and Restaurant Administration Quarterly, 29, (1), 83-87.

Knutson, B. J., and Patton, M. E. (1995). Restaurants can find gold among silver hair: Opportunities in the 55+ market . Journal of Hospitality and Leisure Marketing, 1, (3), 79-90.

Kokko, T. (2005). Offering development in the restaurant sector: A comparison between customer perception and management beliefs. Unpublished doctoral thesis. Helsinki, Finland: Hanken School of Economics.

Kotler, P., Bowen, J. T., and Makens, J. C. (2006). Marketing for Hospitality and Tourism 4th (ed.). New Jersey: pearson Education Inc.

Kovjanic, G. (2014). Islamic Tourism as a Factor of the Middle East Regional Development. Turizam, 18, (1), 33-43.

Kriegl, U. (2000). International Hospitality Management. The Cornell Hotel and Restaurant Administration Quarterly, 41,(2), 64-71.

Kuo, C.M. (2009). The Managerial Implication of an Analysis of Tourist Profiles and International Hotel Employees Service Attitude. International Journal of Hospitality, 28, (1), 302-309.

Kwenga, J. M. (2012). Operational strategies used by church guest houses in promoting domestic tourism through conferencing in Nairobi, Kenya. Kenya: Kenyatta University Library.

Lam, T. and Zhang, H. (1999). Service Quality of Travel Agents: The Case of Travel Agents in Hong Kong. Tourism Management, 20, (3), 341-349.

Lewis, R. (1985). Getting the most from Marketing Research [Part V] Predicting Hotel Choice: The Attribute Underlying Perception. The Cornell Hotel and Restaurant Administration Quarterly, 26, (3), 82-96.

Lewis, R. C., and Chambers, R. E. (1989). Marketing Leadership in Hospitality. New York: Van Nostrand Reinhold.

Lewis, R.C. (1983). Getting the most from Marketing research. The Cornell Hotel and Restaurant Administration Quarterly, 24, (3), 25-35.

Lim, H. (2010). Understanding American customer perceptions on Japanese food and services in the U.S. Unpublished master's thesis . Las Vegas : University of Nevada.

Liu, Y., and Jang, S. (2009). Perceptions of chinese restaurants in the U.S.: What affects customer satisfaction and behavioral intentions? International Journal of Hospitality Management, 28, 338-348.

Madugba, R. C. (2016). Hospitality Industry in Lagos Can Generate over N846b yearly. Lagos: The Nation Newspaper; July 8.

Mariner, T. (1995). Facing the security challenge. The Bottom Line, 10, (4), 36.

Mattila, A. S. (2001). Emotional Bonding and Restaurant Loyalty. Cornell Hotel and Restaurant Administration Querterly, 42 , (6), 73-79.

Mayo, C., and Collegain, B. (1997). Industry Report. Academic Research Library, 27, (2), 96.

McCleary, K.W., Weaver, P.A., and Hutchinson, J.C. (1993). Hotel Choice Attribute as they Relate to Business Travel Situations. Journal of Travel Research, 32, (2), 42-48.

McColl-Kennedy, J. R., and White, T. (1997). Service provider training programs at odds with customer requirements in fivestar hotels. Journal of Service Marketing, 11, (4), 249-264.

Mohsin, A. and Lockyer, T. (2010). Customer perceptions of service quality in luxury hotels in New Delhi, India: an exploratory study. International Journal of Contemporary Hospitality Management, 22, ( 2), 12-32.

Nikki, F., Pietro, C., Sunet, L., Basheena, B., Osere, A., Nicolas, V, and Michael, M. (2015). The African Traveller. Sunninghill, South Africa: PWC'S Hospitality Industry Group.

Oh, H. (1999). Service quality, customer satisfaction, and customer value: a holistic perspective. International Journal of Hospitality Management, 18, (1), 67-82.

Pallant, J. (2010). SPSS Survival Manual: A Step by Step Guide to Data Analysis Using SPSS. McGraw-Hill International.

PricewaterhouseCoopers. (2015). Hospitality Outlook; 2015-2017. South Africa: PricewaterhouseCoopers.

PricewaterhouseCoopers. (2017). African Insights Hotels outlook: 2017-2021. Retrieved August 11, 2018, from www.pwc.co.za/ hospitality-and-leisure.

Ramanathan, U. (2010). Guests"e perceptions on attribute influencing customer loyalty: An analysis for UK hotels. International Journal of Contemporary Hospitality Management, 17, 317-328.

Reichheld, F. F. (1990). Zero defections: Quality comes to services. Havard Business Review, 68, (5), 105-111. 
Reimer, A., and Kuehn, R. (2005). The Impact of Servicescape on Quality Perception. European Journal of Marketing, 39 , 785-808.

Richard, M.D. and Sundaram, D.S. (1993). Lodging Choice Intentions: A Causal Modeling Approach. Journal of Hospitality and Leisure Marketing, 1,(4), 81-98.

Rivers, M.J., Toh, R.S., and Alaoui, M. (1991). Frequent-stayerprograms:thedemographic, behavioural, and attitudinal characteristics of hotel steady sleepers. Journal of Travel Research, 30, (2), 41-45.

Seiders, K., Berry, L.L., and Gresham, L. (2000). Attention retailers: How convenience it is your convenience strategy? Sloan Management Review, 49,(3),79-90.

Sohrabi, B., Vanani, I. R., Tahmasebipur, K., and Fazli, S . (2011). An Exploratory Analysis of Hotel Choice Attribute: A Comprehensive Survey of Tehran Hotels. International Journal of Hospitality Management, 31, (1), 96-106.

Sun, S., \& Lu, W. (2005). Evaluating the Performance of the Taiwanese Hotel Industry using a Weight Slacks-based Measure. Asia-Pacific Journal of Operational Research, 22,(4), 487-512.

Taninecz, G. (1990). 1990 Business Traveller Survey. Hotel and Motel Management, 205, (1), 29-32.

Tsai, H., Yeung, S., and Yim, P.H. (2011). Hotel choice criteria used by mainland Chinese and foreign individual travelers to Hong Kong. International Journal of Hospitality and Tourism Administration, 12, (3), 252-267.

United Nations World Tourism Organization (UNWTO). (2013). Tourism Highlights. Retrieved March 4th, 2019, from www.e-unwto.org/doi/pdf/10.18111/9789284415427

Wakefield, K. L., and Blodgett, J. G. (1996). The effects of the servicescape on custom behavioral intentions in leisure service setting. Journal of Services Marketing, 10, (6), 4561.

Wakefield, K. L.,and Blodgett, J. G. (1994). Theimportanceofservicescapesinleisureservice settings. The Journal of Services Marketing, 8, (3), 66-76.

Wuest, B.E.S., Tas, R.F., and Emenheiser, D.A. (1996). What do Mature Travellers Perceive as Important Hotel/ Motel Customer Service? Hospitality Research Journal , 20 (2),77-93.

Xue, G., Sun, G., \& Hou, W. (2008). An Analysis of Domestic Tourism in Xi'an Based on Tourist Preference and Market Competition. Tourism Tribune, 9, CNKI Journals, China, Retrieved October 15, 2011, from http://en.cnki.com.cn/Article_en/CJFDTOTALLYXK200809010.

Yen, A. and Su, L. (2004). Customers' Satisfaction Measurement Practice in Taiwan Hotels. Hospitality Management, 23,(4), 397-408.

Young, J. A., Clark, P. W., and Mclntyre, F. S. (2007). An exploratory comparison of the casual dining experience. Journal of Foodservice Business Research, 10, (3), 87-105.

Yusoff, F. M., and Abdullah, F. S. C. (2010). What really matters when choosing a hotel? The case of Middle East tourists in Kuala Lumpur, Malaysia. Journal of Business Research, 63, 45-62.

Zeithaml, V. and Bitner, M. (2003). Service Marketing: Integrating Customer Focus across the Firm. New York.: McGrawHill. 